\title{
Removal of Pharmaceuticals from Wastewater by Intermittent Electrocoagulation
}

\author{
Benny Marie B. Ensano ${ }^{1}$, Laura Borea ${ }^{2}$, Vincenzo Naddeo ${ }^{2, *}$, Vincenzo Belgiorno ${ }^{2}$, \\ Mark Daniel G. de Luna ${ }^{1,3}$ and Florencio C. Ballesteros Jr. ${ }^{1,3}$ \\ 1 Environmental Engineering Program, National Graduate School of Engineering, \\ University of the Philippines, Diliman, 1101 Quezon City, Philippines; bmensano@yahoo.com (B.M.B.E.); \\ mgdeluna@gmail.com (M.D.G.d.L.); balleste@gmail.com (F.C.B.J.) \\ 2 Sanitary and Environmental Engineering Division (SEED), Department of Civil Engineering, \\ University of Salerno, 84084 Fisciano (SA), Italy; lborea@unisa.it (L.B.); v.belgiorno@unisa.it (V.B.) \\ 3 Department of Chemical Engineering, University of the Philippines, Diliman, 1101 Quezon City, Philippines \\ * Correspondence: vnaddeo@unisa.it; Tel.: +39-089-969-333
}

Academic Editor: Wilhelm Püttmann

Received: 17 October 2016; Accepted: 24 January 2017; Published: 31 January 2017

\begin{abstract}
The continuous release of emerging contaminants (ECs) in the aquatic environment, as a result of the inadequate removal by conventional treatment methods, has prompted research to explore viable solutions to this rising global problem. One promising alternative is the use of electrochemical processes since they represent a simple and highly efficient technology with less footprint. In this paper, the feasibility of treating ECs (i.e., pharmaceuticals) using an intermittent electrocoagulation process, a known electrochemical technology, has been investigated. Diclofenac (DCF), carbamazepine (CBZ) and amoxicillin (AMX) were chosen as being representative of highly consumed drugs that are frequently detected in our water resources and were added in synthetic municipal wastewater. The removal efficiencies of both individual and combined pharmaceuticals were determined under different experimental conditions: hydraulic retention time (HRT) $(6,19$ and $38 \mathrm{~h})$, initial concentration $(0.01,4$ and $10 \mathrm{mg} / \mathrm{L})$ and intermittent application $(5 \mathrm{~min} \mathrm{ON} / 20 \mathrm{~min}$ $\mathrm{OFF})$ of current density $\left(0.5,1.15\right.$ and $\left.1.8 \mathrm{~mA} / \mathrm{cm}^{2}\right)$. Results have shown that these parameters have significant effects on pharmaceutical degradation. Maximum removals $(\mathrm{DCF}=90 \%, \mathrm{CBZ}=70 \%$ and $\mathrm{AMX}=77 \%$ ) were obtained at a current density of $0.5 \mathrm{~mA} / \mathrm{cm}^{2}$, an initial concentration of $10 \mathrm{mg} / \mathrm{L}$ and HRT of $38 \mathrm{~h}$.
\end{abstract}

Keywords: diclofenac (DCF); carbamazepine (CBZ); amoxicillin (AMX); emerging contaminants (ECs); electrochemical processes; current density; electric field

\section{Introduction}

The presence of ECs, such as pharmaceuticals, in our water resources has raised great concern among scientists worldwide due to their persistence in nature and ecotoxicological effects on terrestrial and aquatic organisms. Among these pharmaceuticals, diclofenac (DCF), carbamazepine (CBZ) and amoxicillin (AMX) are three of the most frequently detected in the aquatic environment $[1,2]$. DCF is a nonsteroidal anti-inflammatory drug (NSAID) usually administered to alleviate degenerative joint diseases such as rheumatoid arthritis, osteoarthritis, non-articular rheumatism and sport injuries [3]. It is also used to reduce menstrual pain and as veterinary medicine. CBZ is an antiepileptic drug used to control seizures and for the treatment of trigeminal neuralgia and some psychiatric diseases (e.g., bipolar disorders) [4]. AMX, on the other hand, is a broad spectrum antibiotic used to treat bacterial infections caused by susceptible microorganisms [5]. Due to their low biodegradability, they are incompletely removed in conventional wastewater treatment plants, thereby, posing a high risk 
of contamination into the receiving water bodies [6-8]. A maximum concentration of $1.2 \mu \mathrm{g} / \mathrm{L}$ of DCF was detected by Ternes [9] in German Rivers receiving sewage effluents, and $290 \mathrm{ng} / \mathrm{L}$ was measured in the groundwater of Barcelona, Spain [10]. CBZ has the highest concentration $(6.3 \mu \mathrm{g} / \mathrm{L})$ detected among the 32 drug residues investigated in German sewage treatment plant (STP) effluents [9]. In another study [6], it has the second highest average mass load (364 mg/1000 inh/d), out of the 73 pharmaceuticals studied, in the secondary effluent of municipal wastewater treatment plants (WWTPs); DCF ranked eighth while AMX was 26th. AMX has average values of 0.24 and $0.01 \mu \mathrm{g} / \mathrm{L}$ in the WWTP influent and effluent, respectively, as reviewed by Verlicchi et al. [6]. AMX was also found in the surface water of Victoria Harbor, Hong Kong at a maximum concentration of $76 \mathrm{ng} / \mathrm{L}$ [11].

At relatively low concentrations, these three compounds are proven to cause cytological damages on terrestrial and aquatic ecosystems. Triebskorn et al. [12] reported that $1 \mu \mathrm{g} / \mathrm{L}$ of DCF changes the liver ultrastructure, liver glycogen and kidney protein of a rainbow trout (Oncorhynchus mykiss). At lower concentration (10 ng/L), DCF can impair osmoregulatory ability of a green shore crab Carcinus maenas [13]. Almeida et al. [14] proved that beyond the threshold concentration of $3 \mu \mathrm{g} / \mathrm{L}, \mathrm{CBZ}$ causes an impairment of antioxidant enzymes of the clam Ruditapes philippinarum. It can also affect the mortality, emergence and fertility of the non-biting midge Chironomus riparius at a concentration equal to $1.1 \mathrm{mg} / \mathrm{kg}$ [15]. AMX is also toxic toward the algae Cyanophyta Synechococcus leopolensis at concentrations ranging from $50 \mathrm{ng} / \mathrm{L}$ to $50 \mathrm{mg} / \mathrm{L}$ [16] and inhibits the photosynthesis of Synechocystis sp. [17]. It is, therefore, necessary to remove these emerging contaminants from wastewater prior to discharge in receiving waters.

Over the past decades, several technologies have been developed for the treatment of these pharmaceutical compounds from wastewater [18,19]. Among these methods, electrocoagulation is currently gaining attention from the scientific community due to the many advantages it offers over the conventional biological treatment. It is referred to as an environmental technology owing to the fact that it uses a clean reagent (electron) for the abatement of organic and recalcitrant pollutants [20]. It produces less sludge, has compact treatment facility (less footprint) and the possibility of complete automation can be expected [21,22]. A $62 \%$ removal of $12.5 \mathrm{mg} / \mathrm{L} \mathrm{CBZ} \mathrm{was} \mathrm{obtained} \mathrm{by}$ the electrocoagulation process under slightly acidic conditions $(\mathrm{pH} 4)$ with a j $=44 \mathrm{~mA} / \mathrm{cm}^{2} \mathrm{using}$ Al ectrode in the study of Yehya et al. [23]. Liu et al. [24] investigated the electrocoagulation-flotation of DCF in the presence of other NSAIDs, i.e., ibuprofen and ketoprofen, and the results suggested that the addition of a cationic surfactant (cethyl trimethyl ammonium bromide, CTAB) significantly increased the elimination of $100 \mu \mathrm{M}$ DCF $(29.6 \mathrm{mg} / \mathrm{L})$ from synthetic (from $12 \%$ to $97 \%$ DCF removal) and real hospital wastewater (from $27 \%$ to $95 \%$ DCF removal) by applying a current of $0.5 \mathrm{~A}$. About $80 \%$ of $30 \mathrm{mg} / \mathrm{L}$ AMX was eliminated from aqueous solution after $4 \mathrm{~h}$ in a non-optimized electrochemical cell at $2.45 \mathrm{~V}$ potential using an iron anode and titanium plates as the anode and cathode, respectively [25]. In another study [26], the reduction of the concentration of sulfamethoxazole by the electrocoagulation-flotation process with aluminum electrodes was over $80 \%$.

Intermittent electrocoagulation was studied in recent years in order to contrast the high energy consumption and anode passivation phenomenon [27,28]. Ren et al. [29] applied a pulse electro coagulation technology to the treatment of refractory berberine hydrochloride $(\mathrm{BH})$ wastewater and found a removal of $\mathrm{BH}$ and chemical oxygen demand (COD)equal to $90.1 \%$ and $62.6 \%$, respectively.

As discussed above, there are already studies conducted for the removal of these pharmaceuticals from wastewater or synthetic solutions through electrocoagulation, however, only some of them applied intermittent electrocoagulation. Therefore, this is the first study that utilizes a synthetic municipal wastewater contaminated with a mixture of three pharmaceuticals using initial concentrations as low as $0.01 \mathrm{mg} / \mathrm{L}$ per compound along with an intermittent application of low values of current density. The main objective of this research is to investigate the removal from synthetic wastewater of three pharmaceutical compounds (i.e., DCF, CBZ and AMX) through the applications of intermittent electrocoagulation using an aluminium anode. DCF, CBZ and AMX were selected as representative of highly consumed pharmaceuticals under different drug categories (anti-inflammatory, 
antiepileptic and antibiotic) that are currently detected in all sorts of water. The effects of varying experimental conditions such as initial concentration, reaction time and current density on the removal of these compounds were also examined.

\section{Materials and Methods}

\subsection{Chemicals}

All pharmaceuticals under study, i.e., diclofenac sodium salt (DCF), carbamazepine (CBZ), and amoxicillin trihydrate (AMX), were of analytical grade (purity > 99\%) obtained from Sigma-Aldrich and were used without any further purification. The physicochemical characteristics of these compounds are summarized in Table 1.

Table 1. Physicochemical properties of diclofenac, carbamazepine and amoxicillin.

\begin{tabular}{|c|c|c|c|}
\hline & $\begin{array}{l}\text { Diclofenac (DCF) } \\
\text { (Sodium Salt) [30] }\end{array}$ & $\begin{array}{l}\text { Carbamazepine } \\
\text { (CBZ) [31] }\end{array}$ & Amoxicillin (AMX) [32] \\
\hline \multicolumn{4}{|l|}{ Structure } \\
\hline Molecular Formula & $\mathrm{C}_{14} \mathrm{H}_{10} \mathrm{Cl}_{2} \mathrm{NNaO}_{2}$ & $\mathrm{C}_{15} \mathrm{H}_{12} \mathrm{~N}_{2} \mathrm{O}$ & $\mathrm{C}_{16} \mathrm{H}_{19} \mathrm{~N}_{3} \mathrm{O}_{5} \mathrm{~S} \cdot 3 \mathrm{H}_{2} \mathrm{O}$ \\
\hline CAS No. & $15,307-79-6$ & $298-46-4$ & $61336-70-7$ \\
\hline Usage & $\begin{array}{c}\text { Analgesic, } \\
\text { Anti-inflammatory }\end{array}$ & $\begin{array}{c}\text { Analgesic, } \\
\text { Antiepileptic }\end{array}$ & Antibiotic \\
\hline $\begin{array}{l}\text { Molecular weight } \\
\left(\mathrm{gmol}^{-1}\right)\end{array}$ & 318.13 & 236.27 & 419.45 \\
\hline $\mathrm{pKa}$ & 4.3 & $2.3,13.9[33]$ & $2.4,7.4,9.6$ \\
\hline $\begin{array}{l}\text { Water Solubility } \\
\left(\mathrm{gL}^{-1}\right)\left(\text { at } 25^{\circ} \mathrm{C}\right)\end{array}$ & 2.37 & 0.018 & $1-3$ \\
\hline
\end{tabular}

A specified amount of each pharmaceutical was added to $1.8 \mathrm{~L}$ of synthetic municipal wastewater having the following composition (in $\mathrm{mg} / \mathrm{L}$ ) which is in accordance to previous studies [34-37]: $\mathrm{C}_{6} \mathrm{H}_{12} \mathrm{O}_{6}$ (200), $\mathrm{C}_{12} \mathrm{H}_{22} \mathrm{O}_{11}$ (200), protein (68.33), $\left(\mathrm{NH}_{4}\right)_{2} \mathrm{SO}_{4}$ (66.73), $\mathrm{NH}_{4} \mathrm{Cl}(10.91), \mathrm{KH}_{2} \mathrm{PO}_{4}(4.43)$, $\mathrm{K}_{2} \mathrm{HPO}_{4}(9.0), \mathrm{MgSO}_{4} 7 \mathrm{H}_{2} \mathrm{O}(21), \mathrm{MnSO}_{4} \mathrm{H}_{2} \mathrm{O}(2.68), \mathrm{NaHCO}_{3}(30), \mathrm{CaCl}_{2} 6 \mathrm{H}_{2} \mathrm{O}(19.74)$ and $\mathrm{FeCl}_{3} 6 \mathrm{H} 2 \mathrm{O}$ (0.14). All solutions were prepared without $\mathrm{pH}$ adjustment using ultra-pure water obtained from a Millipore Milli-Q system with resistivity $>18 \mathrm{MO} \mathrm{cm}$ at room temperature. The main physical-chemical characteristics of synthetic wastewater used in this study are COD [mg/L] $555.12 \pm 33.53, \mathrm{UV}_{254}\left[\mathrm{~cm}^{-1}\right]$ $0.12 \pm 0.02, \mathrm{NH}_{4}-\mathrm{N}[\mathrm{mg} / \mathrm{L}] 26.54 \pm 2.58, \mathrm{NO}_{3}-\mathrm{N}$ [mg/L] Not detected, $\mathrm{PO}_{4}-\mathrm{P}$ [mg/L] 9.24 \pm 2.23, $\mathrm{pH} 7.15 \pm 0.32$, temperature $\left[{ }^{\circ} \mathrm{C}\right] 19.51 \pm 1.32$, redox potential (ORP) $[\mathrm{mV}] 182.22 \pm 45.22$, Conductivity $[\mu \mathrm{S} / \mathrm{cm}] 283.61 \pm 26.11$. Characteristics of the synthetic wastewater are similar to a previous study [37].

\subsection{Experimental Setup}

The experimental setup is shown in Figure 1. Batch experiments were carried out in a 1.8 L electrochemical reactor with aluminium $(5 \mathrm{~cm} \times 16.5 \mathrm{~cm} \times 0.2 \mathrm{~cm})$ and stainless steel $(6 \mathrm{~cm} \times 16.5 \mathrm{~cm} \times 0.2 \mathrm{~cm})$ plates as the anode and cathode, respectively. The electrode distance was maintained at $5 \mathrm{~cm}$ during electrolysis. A direct current was supplied by a DC regulated power source (TTi CPX400S 420W DC Power Supply) at an intermittent application of $5 \mathrm{~min}$ ON/20 min OFF. A mixing speed of $300 \mathrm{rpm}$ was performed using a magnetic stirrer to ensure good mixing in the reactor, minimize regional differences and break up flocs. It is comparable to the different stirring speed used in other studies [38-40]. Sodium hypochlorite was used to clean the electrodes before starting the experiment. 


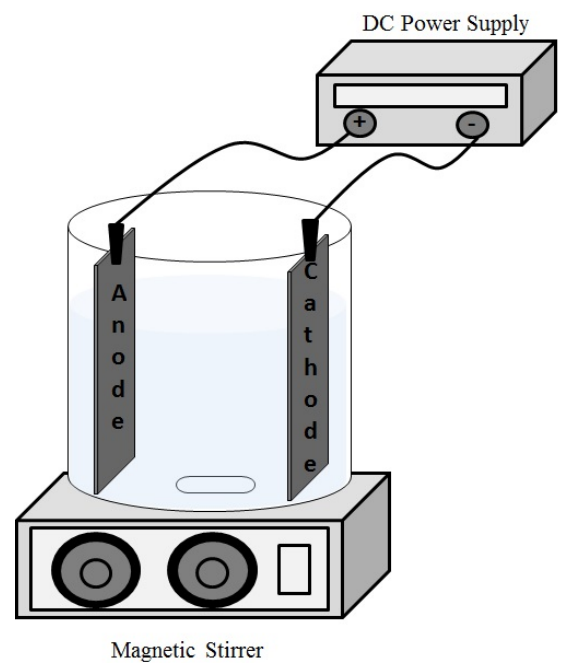

Figure 1. Experimental setup of the electro-chemical reactor.

A total of 21 experimental runs were performed to investigate the influence of different parameters (i.e., initial pharmaceutical concentration, reaction time and current density) on the removal rate of studied pharmaceuticals (Table 2). Synthetic solutions of simulated municipal wastewater (SWW) with or without added pharmaceuticals (DCF, CBZ, AMX and mixture of the three compounds, MIX) were prepared and the removal efficiencies were determined at varying initial concentrations $(0,0.01,4$ and $10 \mathrm{mg} / \mathrm{L})$, treatment time $(6,19$ and $38 \mathrm{~h})$ and current density $\left(0.5,1.15\right.$ and $\left.1.8 \mathrm{~mA} / \mathrm{cm}^{2}\right)$. The values of the initial concentrations were selected mainly for research interest in order to understand the effects of varying the initial concentration on the removal of the selected pharmaceuticals. They were chosen from the range of levels used in other studies [18,41]. In addition, several studies have detected such concentrations in the influent and effluent of WWTPs [42,43].

Table 2. Experimental runs.

\begin{tabular}{|c|c|c|c|c|c|c|}
\hline \multicolumn{2}{|l|}{ Run } & \multicolumn{3}{|c|}{ Pharmaceutical Initial Concentration (mg/L) } & \multirow{2}{*}{$\begin{array}{l}\text { Hydraulic } \\
\text { Retention Time } \\
\text { (HRT) (h) }\end{array}$} & \multirow{2}{*}{$\begin{array}{c}\text { Current } \\
\text { Density } \\
\left(\mathrm{mA} / \mathrm{cm}^{2}\right)\end{array}$} \\
\hline Group & No. & $\begin{array}{l}\text { Diclofenac } \\
\text { (DCF) }\end{array}$ & $\begin{array}{l}\text { Carbamazepine } \\
\text { (CBZ) }\end{array}$ & $\begin{array}{l}\text { Amoxicillin } \\
\text { (AMX) }\end{array}$ & & \\
\hline Synthetic & 1 & 0 & 0 & 0 & 19 & 0.5 \\
\hline wastewater & 2 & 0 & 0 & 0 & 19 & 1.15 \\
\hline SWW & 3 & 0 & 0 & 0 & 19 & 1.8 \\
\hline \multirow{3}{*}{ DCF } & 4 & 4 & 0 & 0 & 19 & 0.5 \\
\hline & 5 & 4 & 0 & 0 & 19 & 1.15 \\
\hline & 6 & 4 & 0 & 0 & 19 & 1.8 \\
\hline \multirow{3}{*}{ CBZ } & 7 & 0 & 4 & 0 & 19 & 0.5 \\
\hline & 8 & 0 & 4 & 0 & 19 & 1.15 \\
\hline & 9 & 0 & 4 & 0 & 19 & 1.8 \\
\hline \multirow{3}{*}{ AMX } & 10 & 0 & 0 & 4 & 19 & 0.5 \\
\hline & 11 & 0 & 0 & 4 & 19 & 1.15 \\
\hline & 12 & 0 & 0 & 4 & 19 & 1.8 \\
\hline \multirow{9}{*}{$\begin{array}{l}\text { Mixture of three } \\
\text { pharmaceuticals } \\
\text { MIX }\end{array}$} & 13 & 4 & 4 & 4 & 19 & 0.5 \\
\hline & 14 & 4 & 4 & 4 & 19 & 1.15 \\
\hline & 15 & 4 & 4 & 4 & 19 & 1.8 \\
\hline & 16 & 0.01 & 0.01 & 0.01 & 6 & 0.5 \\
\hline & 17 & 0.01 & 0.01 & 0.01 & 19 & 0.5 \\
\hline & 18 & 0.01 & 0.01 & 0.01 & 38 & 0.5 \\
\hline & 19 & 10 & 10 & 10 & 6 & 0.5 \\
\hline & 20 & 10 & 10 & 10 & 19 & 0.5 \\
\hline & 21 & 10 & 10 & 10 & 38 & 0.5 \\
\hline
\end{tabular}




\subsection{Analytical Methods}

Influent and effluent samples were collected and filtered using 1.2- $\mu \mathrm{m}$ glass fiber filters (Whatman, Maidstone, UK). They were then analysed in terms of chemical oxygen demand (COD), ammonia nitrogen $\left(\mathrm{NH}_{4}-\mathrm{N}\right)$ and orthophosphate $\left(\mathrm{PO}_{4}-\mathrm{P}\right)$ according to standard methods [44]. Dissolved oxygen concentration (DO), $\mathrm{pH}$, temperature, conductivity and ORP were obtained using a multiparametric probe (Hanna Instruments, HI769828). Two samples were taken from the reactor after each run for the analysis of dissolved aluminium and iron concentrations. One is filtered using $0.45 \mu \mathrm{m}$ filter paper and the other is not filtered. Then, they are digested with $67 \% \mathrm{HNO}_{3}$ prior to measurement in the inductively coupled plasma-optical emission spectrometer (ICP-OES Spectrometer, Thermo Electron Corp., iCAP 6000 Series) according to standard methods [44]. Dissolved organic carbon (DOC) was measured using total organic carbon (TOC) Analyser (Thermo Scientific, HIPERTOC). Samples were also analysed for $\mathrm{UV}_{254}$ (a measure of ultraviolet absorption at wavelength of $254 \mathrm{~nm}$ ) using a Lambda $12 \mathrm{UV}$-Vis spectrometer (Perkin Elmer, USA). The ratio between $\mathrm{UV}_{254}$ and DOC is known as $\mathrm{SUVA}_{254}$ which is a useful parameter in estimating the dissolved aromatic carbon content in water samples [45]. Meanwhile, the pharmaceutical compounds were analysed using a 4000Q Trap liquid chromatography-mass spectrometry (LC-MS/MS) System (Applied Biosystems, Foster City, CA, USA) in electrospray ionization (ESI)-positive mode with a mobile phase composed of A: $0.1 \%$ formic acid in water and B: acetonitrile-water $(1: 1, v / v)$ solution (limit of quantification lower of $1 \mathrm{ng} / \mathrm{L}$ ). The method detection limit (MDL) was between 0.9 and $8 \mathrm{ng} / \mathrm{L}$ in spiked water samples. The precision of the method, calculated as relative standard deviation, ranged from $0.9 \%$ to $3.0 \%$.

\section{Results and Discussion}

\subsection{Removal of Conventional Pollutants}

$\mathrm{COD}, \mathrm{NH}_{4}-\mathrm{N}$ and $\mathrm{PO}_{4}-\mathrm{P}$ were monitored in this study as they are good indicators of wastewater quality. To evaluate the removal of these conventional pollutants, experiments were carried out for synthetic wastewater contaminated with a mixture of the three compounds (MIX) at varying current densities $\left(\mathrm{j}=0.5,1.15\right.$ and $\left.1.8 \mathrm{~mA} / \mathrm{cm}^{2}\right)$. The initial concentration of each pharmaceutical in the solution was $4 \mathrm{mg} / \mathrm{L}$ and the HRT was $19 \mathrm{~h}$ (Table 2). From the results obtained in the experiments (Figure 2), current density affects both the removal of $\mathrm{COD}$ and $\mathrm{NH}_{4}-\mathrm{N}$ from MIX wastewater. As $\mathrm{j}$ is increased, $\mathrm{COD}$ and $\mathrm{NH}_{4}-\mathrm{N}$ removals are also improved.

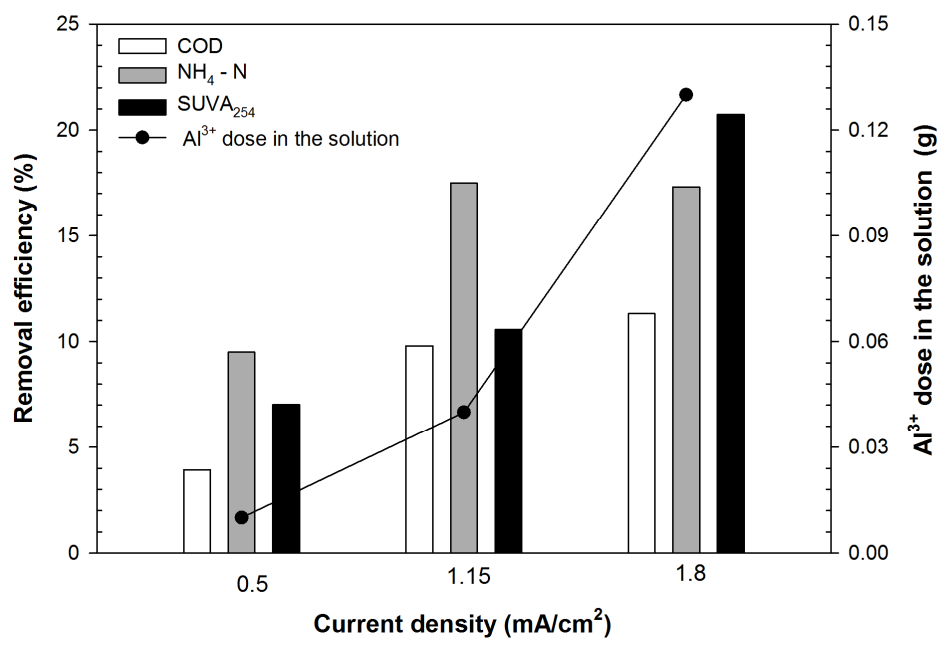

Figure 2. Removal efficiencies of $\mathrm{COD}, \mathrm{NH}_{4}-\mathrm{N}$ and $\mathrm{SUVA}_{254}$ at varying current densities (conditions: initial concentration $=4 \mathrm{mg} / \mathrm{L}, \mathrm{HRT}=19 \mathrm{~h}$ ) and concentration of $\mathrm{Al}^{3+}$ dissolved in the solution at increasing current density. 
In an electrochemical system utilizing a sacrificial anode, which in this case is aluminum, the main mechanisms for the contaminant removal are adsorption, precipitation, electro-flotation and charge neutralization $[24,29,38]$. Upon application of an electric current, $\mathrm{Al}^{3+}$ ions produced by dissolution of the aluminium anode (Equation (1)) immediately undergo spontaneous hydrolysis reactions with $\mathrm{OH}^{-}$ ions, generated through the electro-reduction of water at the cathode (Equation (3)), forming various monomeric species such as $\mathrm{Al}(\mathrm{OH})^{2+}, \mathrm{Al}(\mathrm{OH})_{2}{ }^{+}, \mathrm{Al}_{2}(\mathrm{OH})_{2}{ }^{4+}, \mathrm{Al}(\mathrm{OH})_{4}{ }^{-}$, and polymeric species such as $\mathrm{Al}_{6}(\mathrm{OH})_{15}{ }^{3+}, \mathrm{Al}_{7}(\mathrm{OH})_{17}{ }^{4+}, \mathrm{Al}_{8}(\mathrm{OH})_{20}{ }^{4+}, \mathrm{Al}_{13} \mathrm{O}_{4}(\mathrm{OH})_{24}{ }^{7+}, \mathrm{Al}_{13}(\mathrm{OH})_{34}{ }^{5+}$, which then transform finally into $\mathrm{Al}(\mathrm{OH})_{3(\mathrm{~s})}$ according to complex precipitation kinetics [46,47]. At $\mathrm{pH} 7-8$, the prevailing $\mathrm{Al}$ species are the insoluble $\mathrm{Al}(\mathrm{OH})_{3(\mathrm{~s})}$ (Equation (4)) hydroxides with traces of positive charge complexes [46]. These precipitates act as "swift flocs" and have large surface areas which are helpful for the fast adsorption of contaminants from wastewater [48].

At the Anode:

$$
\begin{gathered}
(\mathrm{Al})_{(\mathrm{s})} \rightarrow \mathrm{Al}^{3+}{ }_{(\mathrm{aq})}+3 \mathrm{e}^{-} \\
2 \mathrm{H}_{2} \mathrm{O} \rightarrow \mathrm{O}_{2(\mathrm{~g})}+5 \mathrm{H}^{+}+5 \mathrm{e}^{-}
\end{gathered}
$$

At the Cathode:

$$
2\left(\mathrm{H}_{2} \mathrm{O}+\mathrm{e}^{-} \rightarrow \frac{1}{2} \mathrm{H}_{2(\mathrm{~g})}+\mathrm{OH}^{-}\right)
$$

In the solution:

$$
\mathrm{Al}^{3+}+3 \mathrm{OH}^{-} \rightarrow \mathrm{Al}(\mathrm{OH})_{3(\mathrm{~s})}
$$

In addition, upon the application of electricity, water electrolysis occurs producing oxygen gas and protons $\left(\mathrm{H}^{+}\right)$at the anode (Equation (2)) and hydrogen gas and hydroxyl anion $\left(\mathrm{OH}^{-}\right)$(Equation (3)) at the cathode. According to Cañizares et al. [47], chemical dissolution of the aluminum anode should also be considered in the electrocoagulation process. It is the result of the oxidation of the aluminum plate with simultaneous reduction of water, forming hydrogen gas (Equation (5)):

$$
2 \mathrm{Al}+6 \mathrm{H}_{2} \mathrm{O} \rightarrow 2 \mathrm{Al}^{3+}+3 \mathrm{H}_{2(\mathrm{~g})}+6 \mathrm{OH}^{-}
$$

The iron concentration was also measured in the solution and showed negligible results which means that the stainless steel cathode did not undergo any appreciable change during the electrocoagulation treatment other than hydrogen evolution as a result of the electro reduction of water. Based on a previous study conducted by Picard et al. [49], the total $\mathrm{H}_{2}$ evolved during electrocoagulation using a stainless steel cathode conforms with the theoretical value calculated using Faraday's law and that no chemical dissolution of the cathode has occurred.

In the present case, for $\mathrm{pH}>7$, the primary mechanism for the removal of organic compounds is sweep coagulation with adsorption of organic substances on amorphous aluminium hydroxide precipitates [50,51]. Consequently, the increasing current density led to an increase of COD removal efficiency because of the increased production of the coagulant $\left(\mathrm{Al}^{3+}\right.$ ions) on the anode (Figure 2).

Electro-flotation is another mechanism for the removal of organic matter [24,29,38]. The production of bubbles, due to hydrogen evolution at the electrodes, contributed to the collection of generated flocs by $\mathrm{H}_{2}$ flotation. Upon increasing the current intensity, the bubble generation rate increases and the bubble size decreases, thus increasing its total surface area and improving pollutants removal efficiency [24] as reported in Figure 2. It should be taken into account that flotation depends on the nature of the organic matter. Anionic compounds are difficult to remove by hydrophobic bubbles [24].

Though the treatment efficiencies increased as the current density increases, low removal of COD $(<15 \%)$ was still observed. This can be attributed to the insufficient amount of coagulants generated which could have improved the removal of organic compounds from the wastewater. According to Faraday's law (Equation (6)), the theoretical $\mathrm{Al}^{3+}$ dissolved in the solution at current densities $0.5,1.15$ and $1.8 \mathrm{~mA} / \mathrm{cm}^{2}$ are $6.31 \mathrm{~g}, 14.52 \mathrm{~g}$ and $22.95 \mathrm{~g}$, respectively. However, as per the actual measurement, 
only $0.01,0.04$ and $0.13 \mathrm{~g}$ of $\mathrm{Al}^{3+}$ were detected in the solution, hence superfaradaic efficiencies can be neglected in this study. This could be attributed to the passivation of the anode surface, found at the end of the batch test due to either the dissolution of aluminum or the directly oxidized film formed on the electrode. Passivation affects the polarization resistance causing lower cell potential than the theoretical value [52]. The passive film, indeed, increases the resistance and reduces the release of the coagulant and bubbles, decreasing the current and removal efficiency [53].

$$
\mathrm{m}=\frac{\mathrm{ItM}}{\mathrm{zF}}
$$

where I corresponds to electric current (A), $t$ is the applied electrocoagulation time (s), $M$ is the molecular mass of aluminum, $\mathrm{z}$ is the valence of metal ions and $\mathrm{F}$ is the Faraday's constant $(96,487 \mathrm{c} / \mathrm{mol})$.

Another important consideration in the determination of the quality of treated water is the concentration of natural organic matter (NOM). NOMs are potential precursors for the formation of disinfection byproducts (DBPs), which are suspected human carcinogens, during tertiary water treatment (i.e., chlorination) [54]. More specifically, humic substances comprise the aromatic fraction of NOMs and were generally perceived to be the primary precursors for DBP formation [45,50]. SUVA 254 is a useful parameter in estimating the dissolved aromatic carbon content in water samples and hence the aquatic humic substances [51]. In the study conducted by Weishaar et al. [45], SUVA 254 has been proven to strongly correlated with the percent of aromaticity of the 13 organic matter isolates obtained from a variety of aquatic environments. From Figure 2, it can be seen that $\mathrm{SUVA}_{254}$ removal efficiencies increase at increasing current density. This means that the presence of an electric current improves the removal of aromatic and humic compounds from wastewater. Ulu et al. [55] suggested that during electrocoagulation, the functional groups of humic acid are attracted to positive $\mathrm{Al}$ species which facilitates their removal. Mohora et al. [56] also added that due to electrocoagulation, high molecular weight fraction of NOMs was degraded into low molecular weight and more hydrophilic compounds which are less prone to coagulate.

On the other hand, complete removal of phosphorus was achieved regardless of the composition of the wastewater and the current density applied. This can be explained by the interactions between aluminium and phosphate ions inside the reactor which resulted in the significant removal of the latter from the solution [57]. Aside from adsorption onto $\mathrm{Al}(\mathrm{OH})_{3}$ coagulants, excess aluminium ions $\left(\mathrm{Al}^{3+}\right)$ react with phosphorous ions to form $(\mathrm{AlOH})_{3}\left(\mathrm{PO}_{4}\right)_{2}(\mathrm{~s})$ and $\mathrm{AlPO}_{4}(\mathrm{~s})$ that precipitate out in the bioreactor according to the following reactions (Equations (7) and (8)) [58]:

$$
\begin{gathered}
3 \mathrm{Al}^{3+}+2 \mathrm{PO}_{4}{ }^{3-}+3 \mathrm{H}_{2} \mathrm{O} \rightarrow \mathrm{Al}(\mathrm{OH})_{3}\left(\mathrm{PO}_{4}\right)_{2(\mathrm{~s})}+3 \mathrm{H}^{+} \\
\mathrm{Al}^{3+}+\mathrm{PO}_{4}{ }^{3-} \rightarrow \mathrm{AlPO}_{4(\mathrm{~s})}
\end{gathered}
$$

Several studies have reached the same conclusion on the phosphorus removal capability of the electrochemical process using aluminum as the anode [37]. Wei et al. [59] integrated the electrocoagulation system with a membrane bioreactor and observed an increase in Ortho-P removal from $18.9 \%$ to $86.6 \%$ after direct current was applied to the bioreactor [60]. The $\mathrm{PO}_{4}-\mathrm{P}$ and total $P$ removal efficiencies of the MBR system with the electrocoagulation unit were $77.2 \%$ and $79.9 \%$, respectively, which were significantly higher than that of the MBR system without the coagulation process $\left(\mathrm{PO}_{4}-\mathrm{P}=59.0 \%\right.$ and total $\left.\mathrm{P}=41.0 \%\right)[61]$.

\subsection{Effects of Parameters on Pharmaceutical Removal}

\subsubsection{Current Density}

To understand the effects of current density (j) on the removal of pharmaceuticals from simulated municipal wastewater, varying current densities $\left(0.5,1.15\right.$ and $\left.1.8 \mathrm{~mA} / \mathrm{cm}^{2}\right)$ were applied intermittently 
(5 min ON and $20 \mathrm{~min}$ OFF) to both individual and mixture component systems at an initial concentration of $4 \mathrm{mg} / \mathrm{L}$ and HRT of $19 \mathrm{~h}$ (Table 2, Run 4-15). The term "removal" is used here for the conversion of the target pharmaceutical to compounds other than the parent compound. As it can be seen in Figure 3, pharmaceutical removal increases at increasing current density. The results are consistent for both systems with the maximum removal obtained at $1.8 \mathrm{~mA} / \mathrm{cm}^{2}$.

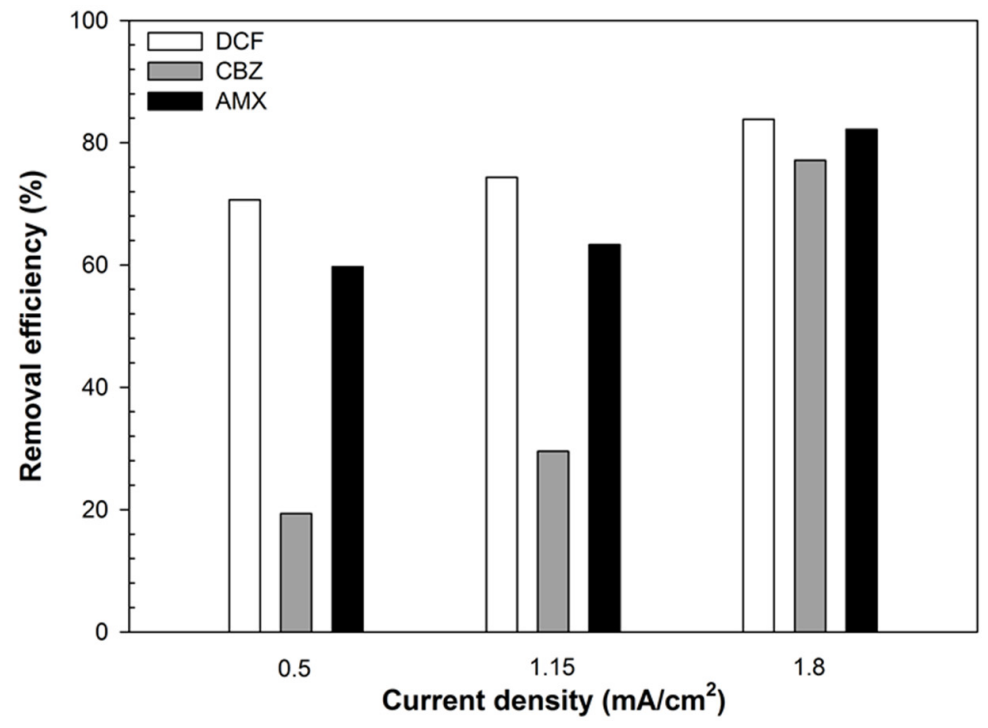

(a)

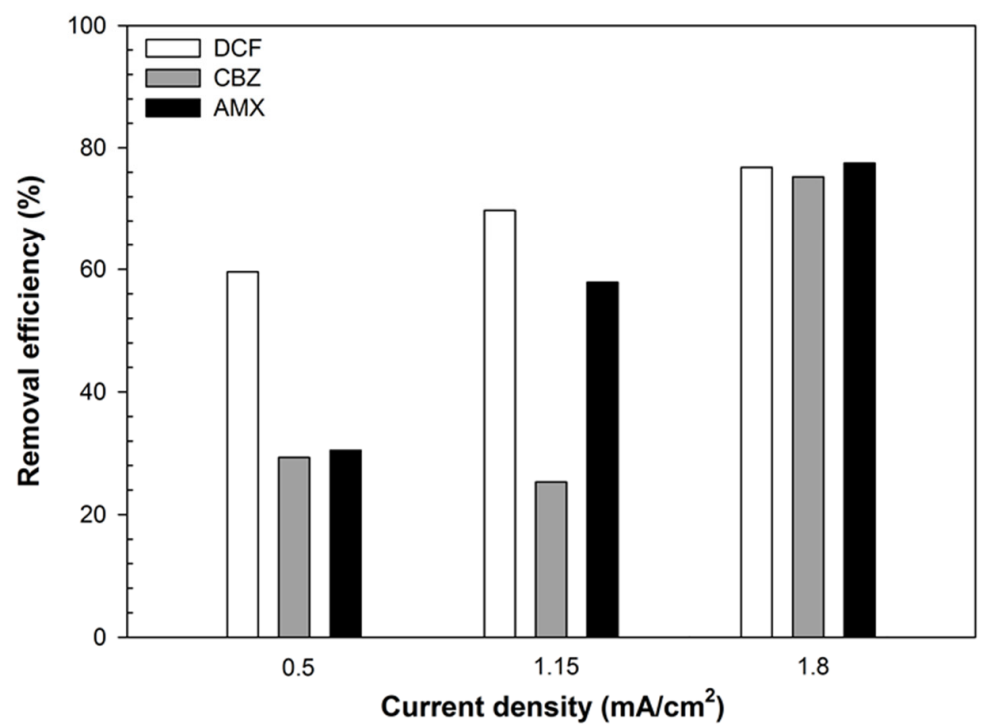

(b)

Figure 3. Effects of current density on the removal of pharmaceuticals by electrochemical processes: (a) Individual pharmaceuticals; (b) Mixture of pharmaceuticals (conditions: initial concentration $=4 \mathrm{mg} / \mathrm{L}, \mathrm{HRT}=19 \mathrm{~h}$ ).

In the electrocoagulation process as previously reported, the removal mechanisms are adsorption onto $\mathrm{Al}(\mathrm{OH})_{3}$ flocs, charge neutralization and electro-flotation [62]. The $\mathrm{pH}$ of the solution is considered to be a key parameter affecting the elimination of pharmaceuticals, however, in this study, the initial $\mathrm{pH}(\mathrm{pH}=7-8)$ of the solution was not adjusted to simulate the typical $\mathrm{pH}$ of municipal wastewater. The generated $\mathrm{Al}^{3+}$ ions formed via electrodissolution of anodes (Equation (1)) react with $\mathrm{OH}^{-}$ions produced through the electro-reduction of water at the cathode (Equation (3)) which 
are then hydrolysed to various metal hydroxide complexes depending on the solution $\mathrm{pH}$ and turn into amorphous $\mathrm{Al}(\mathrm{OH})_{3(\mathrm{~s})}$ (Equation (4)) [47]. Phan et al. [63] mentioned that very hydrophobic compounds with $\mathrm{k}_{\mathrm{ow}}>3$ are generally removed from the aqueous phase via sorption to biosolids. The $\mathrm{k}_{\mathrm{ow}}$ values of the selected pharmaceuticals $(\mathrm{DCF}=0.70, \mathrm{AMX}=0.87, \mathrm{CBZ}=2.45)$ indicate that they have low hydrophobicity and, hence, they are less likely to be removed by adsorption on coagulants or hydrogen bubbles but more likely to be removed by charge neutralization. Indeed, since DCF has an acid dissociation constant value (pKa) of 4.2, it implies that it carries negative charge at neutral $\mathrm{pH}$. Therefore, high uptake of DCF can be observed due to the strong electrostatic attraction between DCF and these complexes. CBZ has a pKa 1 of 2.3 related to the protonation of the $\mathrm{NH}_{2}$ group and $\mathrm{pKa}_{2}$ of 13.9 related to the deprotonation of the amino group [33]. The structure of CBZ is in the molecular state at neutral $\mathrm{pH}$ and $\mathrm{CBZ}$ shows a hydrophobic property when it retains a molecular structure. Nghiem et al. [64] added that CBZ was relatively independent of the solution chemistry and is uncharged at common $\mathrm{pH}$ conditions typical of natural water or wastewater. This is probably the reason why CBZ obtains the lowest removal among the three compounds although it has the higher hydrophobicity. AMX, meanwhile, has three $\mathrm{pKa}$ values due to the ionization of its functional groups, identified as carboxyl $\left(\mathrm{pKa}_{1}=2.68\right)$, amine $\left(\mathrm{pKa}_{2}=7.49\right)$ and phenolic hydroxyl $\left(\mathrm{pKa}_{3}=9.63\right)$ [65]. At $\mathrm{pH} 7-8$, carboxyl groups of $\mathrm{AMX}$ are transformed into $\mathrm{COO}^{-}$(Equation (9)) while amine remains neutral and phenol groups are not protonated or deprotonated within the above $\mathrm{pH}$ range studied [66]. Hence, the removal of AMX in the solution is also due to adsorption onto the flocs as well as charge neutralization by electrostatic attraction between the functional groups and the complexes in the solution.

$$
\equiv \mathrm{COOH} \rightarrow \equiv \mathrm{COO}^{-}+\mathrm{H}^{+}
$$

With increasing current density, the concentration of generated coagulants also increases, hence more pharmaceuticals are adsorbed onto the flocs or neutralized. Consequently, the bubble density increased with current density; the higher the $\mathrm{j}$ values, the smaller the bubble size. Liu et al. [24] cited that, at lower current density, the cathode generated larger and fewer bubbles, and the reaction mechanism was based on coagulation, while at higher current density, the cathode generated bubbles with much higher density and smaller sizes, so the removal mechanism was based on flotation. As it can be seen in Figure 3, generally, there was no significant difference between the removal rates of individual pharmaceutical solution and mixture component-except for AMX at $0.5 \mathrm{~mA} / \mathrm{cm}^{2}$-due to the minimal contribution of their concentration $(4 \mathrm{mg} / \mathrm{L})$ on the total amount of organic compounds in the mixture. The COD and DOC concentrations in the mixture with or without added pharmaceuticals were almost the same (COD $515 \mathrm{mg} / \mathrm{L}$, DOC $200 \mathrm{mg} / \mathrm{L}$ ). The presence of different organic compounds in the solution promotes competitive adsorption between the different species leading to the reduction of adsorption of some organics in the mixture. The effects of this competitive adsorption can be much more highlighted using aqueous solution containing pharmaceuticals only, as observed by Liu et al. [24].

\subsubsection{Initial Pharmaceutical Concentrations}

The effects of varying initial concentration $(0.01,4$ and $10 \mathrm{mg} / \mathrm{L})$ on pharmaceutical removal were investigated using a mixture component system at a current density of $0.5 \mathrm{~mA} / \mathrm{cm}^{2}$ and HRT of $19 \mathrm{~h}$ (Table 2, Run 14, 17 and 20). For CBZ and AMX, degradation efficiencies increase at an increasing initial concentration (Figure 4). This can be attributed to the increase of concentration gradient which means a stronger driving force to overcome all mass transfer resistances of solutes between the aqueous and the solid phase $[67,68]$. As a result, there is better adsorption to electrocoagulants. The initial concentration has little or no effect on DCF removal which ranged from 59.57\% to $62.73 \%$. Among the three compounds, DCF is the most soluble (Table 1), hence, as DCF is adsorbed on the aluminum hydroxide precipitates, it becomes more stable in the solution. As a result, it became more difficult to remove the pharmaceutical, possibly due to an increase in the interaction between the DCF and the adsorbent. 


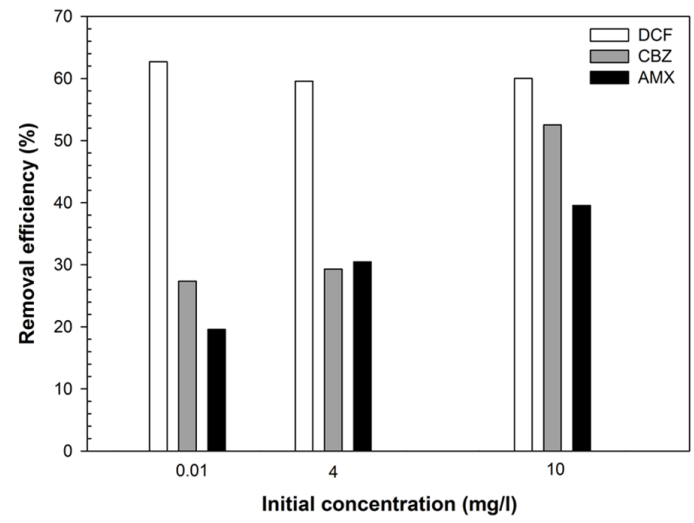

Figure 4. Effects of initial concentration on the removal of pharmaceuticals by electrochemical processes (conditions: $\mathrm{j}=0.5 \mathrm{~mA} / \mathrm{cm}^{2}, \mathrm{HRT}=19 \mathrm{~h}$ ).

\subsubsection{HRT}

Figure 5 shows the removal efficiencies of each pharmaceutical as the HRT is varied at 6,19 and $38 \mathrm{~h}$ under initial concentrations of $0.01 \mathrm{mg} / \mathrm{L}$ and $10 \mathrm{mg} / \mathrm{L}$ at a current density of $0.5 \mathrm{~mA} / \mathrm{cm}^{2}$ (Table 2, Run 16-21). As it can be seen from Figure 5, the removal efficiencies of three pharmaceuticals are directly proportional to the treatment time. Increasing the electrolysis time was known to have a major role in the performance of the electrochemical processes. The longer the treatment time, the more complex the ions are that are generated on the aluminum electrodes and are released into the solution [69]. This, in turn, increases the hydroxide flocs which are responsible for the precipitation and adsorption of the emerging contaminants. For all pharmaceuticals under investigation, the highest removal was obtained after $38 \mathrm{~h}$ of treatment.

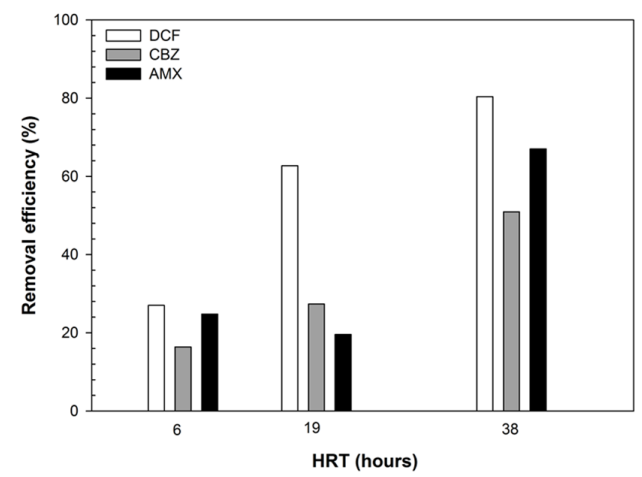

(a)

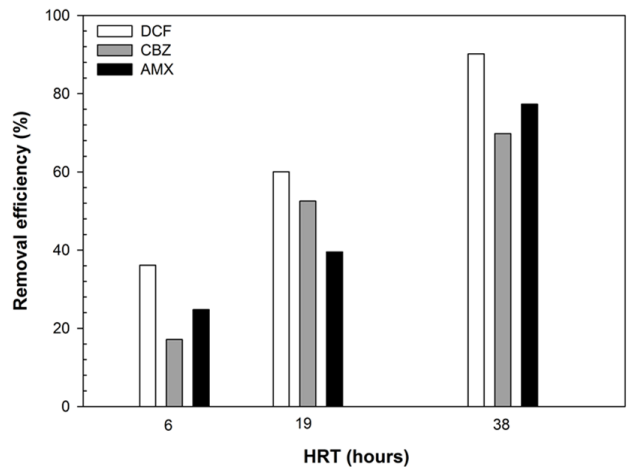

(b)

Figure 5. Effects of HRT on the removal of pharmaceuticals by the electrochemical process at an initial concentration of $0.01 \mathrm{mg} / \mathrm{L}(\mathbf{a})$ and $10 \mathrm{mg} / \mathrm{L}(\mathbf{b})\left(\mathrm{j}=0.5 \mathrm{~mA} / \mathrm{cm}^{2}\right)$. 


\subsection{Effects of the Intermittent Electric Field on Energy Consumption}

Compared with the conventional electrocoagulation process, the application of an intermittent electric field reduces the consumption of the energy as well as of the anode material since the dissolution of the aluminium stops during the power gap. According to energy consumption law (Equation (10)) [29], energy consumption was a function of the $\theta^{2}$ :

$$
\mathrm{Q}=\mathrm{VI} t \theta^{2}
$$

where $\mathrm{Q}(\mathrm{W} h)$ was the energy consumption; $\mathrm{V}(\mathrm{V})$ was the peak voltage; I (A) was the peak current; $\mathrm{t}(\mathrm{s})$ was the reaction time and $\theta$ was the intermittent cycle (in the conventional electrocoagulation process $\theta$ was equal to 1 ).

Considering that in the present case, $\theta$ is equal to 0.2 and $t$ is the HRT applied, the energy consumptions for the different runs are reported in Table 3.

Table 3. Applied voltages, current intensities and energy consumptions of the different experimental runs.

\begin{tabular}{|c|c|c|c|c|c|}
\hline $\mathbf{N}^{\circ}$ Run & HRT (t) (h) & $\begin{array}{l}\text { Current Density }(\mathrm{j}) \\
\left(\mathrm{mA} / \mathrm{cm}^{2}\right)\end{array}$ & $\begin{array}{c}\text { Peak Voltage } \\
\text { (V) }\end{array}$ & $\begin{array}{l}\text { Peak Current } \\
\text { (A) }\end{array}$ & $\begin{array}{c}\text { Energy } \\
\text { Consumption }(\mathrm{Wh})\end{array}$ \\
\hline $1-4-7-10-13-17-20$ & 19 & 0.5 & 19.65 & 0.08 & 1.19 \\
\hline $2-5-8-11-14$ & 19 & 1.15 & 46.07 & 0.19 & 6.65 \\
\hline $3-6-9-12-15$ & 19 & 1.8 & 60.59 & 0.3 & 13.81 \\
\hline 16 & 6 & 0.5 & 19.65 & 0.08 & 0.38 \\
\hline 18 & 38 & 0.5 & 19.65 & 0.08 & 2.39 \\
\hline 19 & 6 & 0.5 & 19.65 & 0.08 & 0.38 \\
\hline 21 & 38 & 0.5 & 19.65 & 0.08 & 2.39 \\
\hline
\end{tabular}

Compared with the continuous electrocoagulation process, the reduction of the energy consumption is equal to $96 \%$ for all the experimental runs.

\section{Conclusions}

This study proves the viability of the intermittent electrocoagulation process in the treatment of conventional pollutants (COD, NOM, $\mathrm{NH}_{4}-\mathrm{N}$ and $\mathrm{PO}_{4}-\mathrm{P}$ ) and emerging contaminants (DCF, CBZ and AMX) from wastewater using a sacrificial aluminum anode. All the three studied parameters, namely current density, initial concentration and treatment time, have been shown to significantly affect the degradation of these pollutants. The interaction between generated $\mathrm{Al}(\mathrm{OH})_{3}$ coagulants and pollutants results to the destabilization and aggregation of suspended particles and the precipitation and adsorption of dissolved contaminants. $\mathrm{H}_{2}$ flotation was also responsible for the collection of micropollutants from wastewater. Higher current density and longer treatment time, therefore, lead to higher pollutant removal due to the increase of coagulant concentration and smaller bubble generation in the solution. Consequently, degradation efficiency increased at the increasing initial concentration of pharmaceuticals due to the stronger driving force which overcomes all mass transfer resistances of solutes between the aqueous and the solid phase. Moreover, the removal of pharmaceuticals from synthetic municipal wastewater contaminated with single pharmaceuticals has been shown to have no significant difference as compared with mixture systems due to the competition between the organic compounds present in the solution. Future studies should be focused on the investigation of the role that $\mathrm{pH}$ plays in the removal of DCF, CBZ and AMX from real municipal wastewater. Isotherm and kinetic studies could also be explored to know the mechanism of adsorption of these micropollutants on the aluminum hydroxide precipitates. Furthermore, the impedance of the anode could also be determined to characterize the passive film across the electrode.

Acknowledgments: The authors would like to thank the Sanitary and Environmental Engineering Division (SEED) Laboratory of University of Salerno for providing the facilities and research fund. The research activities were partially funded by the University of Salerno with the projects n. ORSA167105 and ORSA154525 and are linked to 
the project n. EG16MO01 funded by Italian Ministry of Foreign Affairs and International Cooperation. We also highly acknowledge the University of the Philippines-Diliman and the Engineering Research and Development for Technology (ERDT) through the Department of Science and Technology-Philippines for the Ph.D. Scholarship Grant and Sandwich Program being awarded to BMB Ensano. The authors are also grateful to Anna Farina, Paolo Napodano and Valentina Nobile for the technical support they provided all throughout the experiment.

Author Contributions: Vincenzo Naddeo, Vincenzo Belgiorno and Mark Daniel G. de Luna developed the research idea and planned the research activities, Benny Marie B. Ensano and Laura Borea carried out the research activities and prepared the manuscript, Vincenzo Naddeo and Mark Daniel G. de Luna reviewed the manuscript and supervised the research activities. Vincenzo Belgiorno and Florencio C. Ballesteros, Jr reviewed the final draft of the manuscript.

Conflicts of Interest: The authors declare no conflict of interest.

\section{References}

1. Teijon, G.; Candela, L.; Tamoh, K.; Molina-díaz, A.; Fernández-alba, A.R. Occurrence of emerging contaminants, priority substances (2008/105/CE) and heavy metals in treated wastewater and groundwater at Depurbaix facility (Barcelona, Spain). Sci. Total Environ. 2010, 408, 3584-3595. [CrossRef] [PubMed]

2. Ortiz, S.; García, D.; Pinto, G.; García, P.; Irusta, R. Consumption and occurrence of pharmaceutical and personal care products in the aquatic environment in Spain. Sci. Total Environ. 2013, 444, 451-465. [CrossRef] [PubMed]

3. Tiwari, D.; Lalhriatpuia, C.; Lee, S. Hybrid materials in the removal of diclofenac sodium from aqueous solutions: Batch and column studies. J. Ind. Eng. Chem. 2015, 30, 167-173. [CrossRef]

4. Gros, M.; Petrovic, M.; Ginebreda, A. Occurrence and Elimination of Pharmaceuticals during Conventional Wastewater Treatment. In Emerging and Priority Pollutants in Rivers; Guasch, H., Ginebreda, A., Geiszinger, A., Eds.; Volume 19 of the series The Handbook of Environmental Chemistry; Springer: Berlin/Heidelberg, Germany, 2012; pp. 1-23.

5. Chatterjee, J.; Rai, N.; Sar, S.K. Kinetic Isotherm of Amoxicillin Antibiotic through Adsorption and its Removal by Electrocoagulation. Orient. J. Chem. 2014, 30. [CrossRef]

6. Verlicchi, P.; Al Aukidy, M.; Zambello, E. Occurrence of pharmaceutical compounds in urban wastewater: Removal, mass load and environmental risk after a secondary treatment-A review. Sci. Total Environ. 2012, 429, 123-155. [CrossRef] [PubMed]

7. Papageorgiou, M.; Kosma, C.; Lambropoulou, D. Seasonal occurrence, removal, mass loading and environmental risk assessment of 55 pharmaceuticals and personal care products in a municipal wastewater treatment plant in Central Greece. Sci. Total Environ. 2016, 543, 547-569. [CrossRef] [PubMed]

8. Luo, Y.; Guo, W.; Ngo, H.H.; Nghiem, L.D.; Hai, F.I.; Zhang, J.; Liang, S.; Wang, X.C. A review on the occurrence of micropollutants in the aquatic environment and their fate and removal during wastewater treatment. Sci. Total Environ. 2014, 473-474, 619-641. [CrossRef] [PubMed]

9. Ternes, T.A. Occurrence of drugs in German sewage treatment plants and rivers. Water Res. 1998, 32, 3245-3260. [CrossRef]

10. López-Serna, R.; Jurado, A.; Vázquez-Suñé, E.; Carrera, J.; Petrović, M.; Barceló, D. Occurrence of 95 pharmaceuticals and transformation products in urban groundwaters underlying the metropolis of Barcelona, Spain. Environ. Pollut. 2013, 174, 305-315. [CrossRef] [PubMed]

11. Minh, T.B.; Leung, H.W.; Loi, I.H.; Chan, W.H.; So, M.K.; Mao, J.Q.; Choi, D.; Lam, J.C.W.; Zheng, G.; Martin, M.; et al. Antibiotics in the Hong Kong metropolitan area: Ubiquitous distribution and fate in Victoria Harbour. Mar. Pollut. Bull. 2009, 58, 1052-1062. [CrossRef] [PubMed]

12. Triebskorn, R.; Casper, H.; Scheil, V.; Schwaiger, J. Ultrastructural effects of pharmaceuticals (carbamazepine, clofibric acid, metoprolol, diclofenac) in rainbow trout (Oncorhynchus mykiss) and common carp (Cyprinus carpio). Anal. Bioanal. Chem. 2007, 387, 1405-1416. [CrossRef] [PubMed]

13. Eades, C.; Waring, C.P. The effects of diclofenac on the physiology of the green shore crab Carcinus maenas. Mar. Environ. Res. 2010, 69 (Suppl. 1), S46-S48. [CrossRef] [PubMed]

14. Almeida, Â.; Freitas, R.; Calisto, V.; Esteves, V.I.; Schneider, R.J.; Soares, A.M.V.M.; Figueira, E. Chronic toxicity of the antiepileptic carbamazepine on the clam Ruditapes philippinarum. Comp. Biochem. Physiol. Part C Toxicol. Pharmacol. 2015, 172-173, 26-35. [CrossRef] [PubMed] 
15. Heye, K.; Becker, D.; Lütke Eversloh, C.; Durmaz, V.; Ternes, T.A.; Oetken, M.; Oehlmann, J. Effects of carbamazepine and two of its metabolites on the non-biting midge Chironomus riparius in a sediment full life cycle toxicity test. Water Res. 2016, 98, 19-27. [CrossRef] [PubMed]

16. Andreozzi, R.; Caprio, V.; Ciniglia, C.; de Champdoré, M.; Lo Giudice, R.; Marotta, R.; Zuccato, E. Antibiotics in the Environment: Occurrence in Italian STPs, Fate, and Preliminary Assessment on Algal Toxicity of Amoxicillin. Environ. Sci. Technol. 2004, 38, 6832-6838. [CrossRef] [PubMed]

17. Pan, X.; Deng, C.; Zhang, D.; Wang, J.; Mu, G.; Chen, Y. Toxic effects of amoxicillin on the photosystem II of Synechocystis sp. characterized by a variety of in vivo chlorophyll fluorescence tests. Aquat. Toxicol. 2008, 89, 207-213. [CrossRef] [PubMed]

18. Secondes, M.F.N.; Naddeo, V.; Belgiorno, V.; Ballesteros, F., Jr. Removal of emerging contaminants by simultaneous application of membrane ultrafiltration, activated carbon adsorption, and ultrasound irradiation. J. Hazard. Mater. 2014, 264, 342-349. [CrossRef] [PubMed]

19. Rizzo, L.; Meric, S.; Guida, M.; Kassinos, D.; Belgiorno, V. Heterogenous photocatalytic degradation kinetics and detoxification of an urban wastewater treatment plant effluent contaminated with pharmaceuticals. Water Res. 2009, 43, 4070-4078. [CrossRef] [PubMed]

20. Zhang, C.; Jiang, Y.; Li, Y.; Hu, Z.; Zhou, L.; Zhou, M. Three-dimensional electrochemical process for wastewater treatment: A general review. Chem. Eng. J. 2013, 228, 455-467. [CrossRef]

21. Chen, G. Electrochemical technologies in wastewater treatment. Sep. Purif. Technol. 2004, 38, 11-41. [CrossRef]

22. Mollah, M.Y.A.; Schennach, R.; Parga, J.R.; Cocke, D.L. Electrocoagulation (EC)—Science and applications. J. Hazard. Mater. 2001, 84, 29-41. [CrossRef]

23. Yehya, T.; Favier, L.; Kadmi, Y.; Audonnet, F.; Fayad, N.; Gavrilescu, M.; Vial, C. Removal of carbamazepine by electrocoagulation: Investigation of some key operational parameters. Environ. Eng. Manag. J. 2015, 14, 639-645.

24. Liu, Y.-J.; Lo, S.-L.; Liou, Y.-H.; Hu, C.-Y. Removal of nonsteroidal anti-inflammatory drugs (NSAIDs) by electrocoagulation-flotation with a cationic surfactant. Sep. Purif. Technol. 2015, 152, 148-154. [CrossRef]

25. Padilla-Robles, B.G.; Alonso, A.; Martínez-Delgadillo, S.A.; González-Brambila, M.; Jaúregui-Haza, U.J.; Ramírez-Muñoz, J. Electrochemical degradation of amoxicillin in aqueous media. Chem. Eng. Process. Process Intensif. 2015, 94, 93-98. [CrossRef]

26. Martins, A.F.; Mallmann, C.A.; Arsand, D.R.; Mayer, F.M.; Brenner, C.G.B. Occurrence of the Antimicrobials Sulfamethoxazole and Trimethoprim in Hospital Effluent and Study of Their Degradation Products after Electrocoagulation. CLEAN Soil Air Water 2011, 39, 21-27. [CrossRef]

27. Zhou, J.; Deng, C.; Si, S.; Shi, Y.; Zhao, X. Study on the effect of EDTA on the photocatalytic reduction of mercury onto nanocrystalline titania using quartz crystal microbalance and differential pulse voltammetry. Electrochimica Acta 2011, 56, 2062-2067. [CrossRef]

28. Xie, K.; Sun, L.; Wang, C.; Lai, Y.; Wang, M.; Chen, H.; Lin, C. Photoelectrocatalytic properties of Ag nanoparticles loaded $\mathrm{TiO}_{2}$ nanotube arrays prepared by pulse current deposition. Electrochimica Acta 2010, 55, 7211-7218. [CrossRef]

29. Ren, M.; Song, Y.; Xiao, S.; Zeng, P.; Peng, J. Treatment of berberine hydrochloride wastewater by using pulse electro-coagulation process with Fe electrode. Chem. Eng. J. 2011, 169, 84-90. [CrossRef]

30. Acero, J.L.; Benitez, F.J.; Real, F.J.; Teva, F. Micropollutants removal from retentates generated in ultrafiltration and nanofiltration treatments of municipal secondary effluents by means of coagulation, oxidation, and adsorption processes. Chem. Eng. J. 2016, 289, 48-58. [CrossRef]

31. Comerton, A.M.; Andrews, R.C.; Bagley, D.M.; Yang, P. Membrane adsorption of endocrine disrupting compounds and pharmaceutically active compounds. J. Membr. Sci. 2007, 303, 267-277. [CrossRef]

32. Hu, D.; Wang, L. Adsorption of amoxicillin onto quaternized cellulose from flax noil: Kinetic, equilibrium and thermodynamic study. J. Taiwan Inst. Chem. Eng. 2016, 64, 227-234. [CrossRef]

33. Rao, Y.; Yang, H.; Xue, D.; Guo, Y.; Qi, F.; Ma, J. Sonolytic and sonophotolytic degradation of Carbamazepine: Kinetic and mechanisms. Ultrason. Sonochem. 2016, 32, 371-379. [CrossRef] [PubMed]

34. Yang, P.Y.; Cao, K.; Kim, S.J. Entrapped Mixed Microbial Cell Process for Combined Secondary and Tertiary Wastewater Treatment. Water Environ. Res. 2002, 74, 226-234. [CrossRef] [PubMed]

35. Li, J.; Zhang, X.; Cheng, F.; Liu, Y. New insights into membrane fouling in submerged MBR under sub-critical flux condition. Bioresour. Technol. 2013, 137, 404-408. [CrossRef] [PubMed] 
36. Li, X.; Gao, F.; Hua, Z.; Du, G.; Chen, J. Treatment of synthetic wastewater by a novel MBR with granular sludge developed for controlling membrane fouling. Sep. Purif. Technol. 2005, 46, 19-25. [CrossRef]

37. Borea, L.; Naddeo, V.; Belgiorno, V. Application of electrochemical processes to membrane bioreactors for improving nutrient removal and fouling control. Environ. Sci. Pollut. Res. 2017, 24, 321-333. [CrossRef] [PubMed]

38. Farhadi, S.; Aminzadeh, B.; Torabian, A.; Khatibikamal, V.; Alizadeh Fard, M. Comparison of COD removal from pharmaceutical wastewater by electrocoagulation, photoelectrocoagulation, peroxi-electrocoagulation and peroxi-photoelectrocoagulation processes. J. Hazard. Mater. 2012, 219-220, 35-42. [CrossRef] [PubMed]

39. Kuokkanen, V.; Kuokkanen, T.; Rämö, J.; Lassi, U.; Roininen, J. Removal of phosphate from wastewaters for further utilization using electrocoagulation with hybrid electrodes-Techno-economic studies. J. Water Process Eng. 2015, 8, e50-e57. [CrossRef]

40. Elabbas, S.; Ouazzani, N.; Mandi, L.; Berrekhis, F.; Perdicakis, M.; Pontvianne, S.; Pons, M.-N.; Lapicque, F.; Leclerc, J.-P. Treatment of highly concentrated tannery wastewater using electrocoagulation: Influence of the quality of aluminium used for the electrode. J. Hazard. Mater. 2016, 319, 69-77. [CrossRef] [PubMed]

41. Bui, T.X.; Choi, H. Adsorptive removal of selected pharmaceuticals by mesoporous silica SBA-15. J. Hazard. Mater. 2009, 168, 602-608. [CrossRef] [PubMed]

42. Cruz-Morató, C.; Ferrando-Climent, L.; Rodriguez-Mozaz, S.; Barceló, D.; Marco-Urrea, E.; Vicent, T.; Sarrà, M. Degradation of pharmaceuticals in non-sterile urban wastewater by Trametes versicolor in a fluidized bed bioreactor. Water Res. 2013, 47, 5200-5210. [CrossRef] [PubMed]

43. Evgenidou, E.N.; Konstantinou, I.K.; Lambropoulou, D.A. Occurrence and removal of transformation products of PPCPs and illicit drugs in wastewaters: A review. Sci. Total Environ. 2015, 505, 905-926. [CrossRef] [PubMed]

44. Metodi Analitici per le Acque; Manuali e Linee Guida 29/2003; APAT-IRSA/CNR: Roma, Italy, 2003.

45. Weishaar, J.L.; Aiken, G.R.; Bergamaschi, B.A.; Fram, M.S.; Fujii, R.; Mopper, K. Evaluation of Specific Ultraviolet Absorbance as an Indicator of the Chemical Composition and Reactivity of Dissolved Organic Carbon. Environ. Sci. Technol. 2003, 37, 4702-4708. [CrossRef] [PubMed]

46. Kartikaningsih, D.; Shih, Y.-J.; Huang, Y.-H. Boron removal from boric acid wastewater by electrocoagulation using aluminum as sacrificial anode. Sustain. Environ. Res. 2016, 26, 150-155. [CrossRef]

47. Cañizares, P.; Carmona, M.; Lobato, J.; Martínez, F.; Rodrigo, M.A. Electrodissolution of Aluminum Electrodes in Electrocoagulation Processes. Ind. Eng. Chem. Res. 2005, 44, 4178-4185. [CrossRef]

48. Fajardo, A.S.; Rodrigues, R.F.; Martins, R.C.; Castro, L.M.; Quinta-Ferreira, R.M. Phenolic wastewaters treatment by electrocoagulation process using Zn anode. Chem. Eng. J. 2015, 275, 331-341. [CrossRef]

49. Picard, T.; Cathalifaud-Feuillade, G.; Mazet, M.; Vandensteendam, C. Cathodic dissolution in the electrocoagulation process using aluminium electrodes. J. Environ. Monit. 2000, 2, 77-80. [CrossRef] [PubMed]

50. Ates, N.; Kitis, M.; Yetis, U. Formation of chlorination by-products in waters with low SUVA-Correlations with SUVA and differential UV spectroscopy. Water Res. 2007, 41, 4139-4148. [CrossRef] [PubMed]

51. Chellam, S.; Sari, M.A. Aluminum electrocoagulation as pretreatment during microfiltration of surface water containing NOM: A review of fouling, NOM, DBP, and virus control. J. Hazard. Mater. 2016, 304, 490-501. [CrossRef] [PubMed]

52. Pino, M.; Chacón, J.; Fatás, E.; Ocón, P. Performance of commercial aluminium alloys as anodes in gelled electrolyte aluminium-air batteries. J. Power Sources 2015, 299, 195-201. [CrossRef]

53. He, C.-C.; Hu, C.-Y.; Lo, S.-L. Evaluation of sono-electrocoagulation for the removal of Reactive Blue 19 passive film removed by ultrasound. Sep. Purif. Technol. 2016, 165, 107-113. [CrossRef]

54. Hua, G.; Reckhow, D.A.; Abusallout, I. Correlation between SUVA and DBP formation during chlorination and chloramination of NOM fractions from different sources. Chemosphere 2015, 130, 82-89. [CrossRef] [PubMed]

55. Ulu, F.; Barışçı, S.; Kobya, M.; Sillanpää, M. An evaluation on different origins of natural organic matters using various anodes by electrocoagulation. Chemosphere 2015, 125, 108-114. [CrossRef] [PubMed]

56. Mohora, E.; Rončević, S.; Agbaba, J.; Tubić, A.; Mitić, M.; Klašnja, M.; Dalmacija, B. Removal of arsenic from groundwater rich in natural organic matter (NOM) by continuous electrocoagulation/flocculation (ECF). Sep. Purif. Technol. 2014, 136, 150-156. [CrossRef] 
57. Bani-Melhem, K.; Smith, E. Grey water treatment by a continuous process of an electrocoagulation unit and a submerged membrane bioreactor system. Chem. Eng. J. 2012, 198-199, 201-210. [CrossRef]

58. Ensano, B.M.B.; Borea, L.; Naddeo, V.; Belgiorno, V.; de Luna, M.D.G.; Ballesteros, F.C.J. Combination of Electrochemical Processes with Membrane Bioreactors for Wastewater Treatment and Fouling Control: A Review. Wastewater Manag. 2016, 57. [CrossRef]

59. Wei, V.; Oleszkiewicz, J.A.; Elektorowicz, M. Nutrient removal in an electrically enhanced membrane bioreactor. Water Sci. Technol. 2009, 60, 3159-3163. [CrossRef] [PubMed]

60. Wei, V.; Elektorowicz, M.; Oleszkiewicz, J.A. Electrically enhanced MBR system for total nutrient removal in remote northern applications. Water Sci. Technol. 2012, 65, 737-742. [CrossRef] [PubMed]

61. Kim, H.-G.; Jang, H.-N.; Kim, H.-M.; Lee, D.-S.; Chung, T.-H. Effect of an electro phosphorous removal process on phosphorous removal and membrane permeability in a pilot-scale MBR. Desalination 2010, 250, 629-633. [CrossRef]

62. Cañizares, P.; Martínez, F.; Jiménez, C.; Lobato, J.; Rodrigo, M.A. Coagulation and Electrocoagulation of Wastes Polluted with Dyes. Environ. Sci. Technol. 2006, 40, 6418-6424. [CrossRef] [PubMed]

63. Phan, H.V.; Hai, F.I.; McDonald, J.A.; Khan, S.J.; Zhang, R.; Price, W.E.; Broeckmann, A.; Nghiem, L.D. Nutrient and trace organic contaminant removal from wastewater of a resort town: Comparison between a pilot and a full scale membrane bioreactor. Int. Biodeterior. Biodegrad. 2015, 102, 40-48. [CrossRef]

64. Nghiem, L.D.; Schäfer, A.I.; Elimelech, M. Role of electrostatic interactions in the retention of pharmaceutically active contaminants by a loose nanofiltration membrane. J. Membr. Sci. 2006, 286, 52-59. [CrossRef]

65. Goddard, A.F.; Jessa, M.J.; Barrett, D.A.; Shaw, P.N.; Idström, J.P.; Cederberg, C.; Spiller, R.C. Effect of omeprazole on the distribution of metronidazole, amoxicillin, and clarithromycin in human gastric juice. Gastroenterology 1996, 111, 358-367. [CrossRef] [PubMed]

66. Putra, E.K.; Pranowo, R.; Sunarso, J.; Indraswati, N.; Ismadji, S. Performance of activated carbon and bentonite for adsorption of amoxicillin from wastewater: Mechanisms, isotherms and kinetics. Water Res. 2009, 43, 2419-2430. [CrossRef] [PubMed]

67. Antunes, M.; Esteves, V.I.; Guégan, R.; Crespo, J.S.; Fernandes, A.N.; Giovanela, M. Removal of diclofenac sodium from aqueous solution by Isabel grape bagasse. Chem. Eng. J. 2012, 192, 114-121. [CrossRef]

68. Khazrajy, O. Adsorption of Ciprofloxacin Hydrochloride from Aqueous Solution by Iraqi Porcelinaite Adsorbent. ResearchGate 2014, 17, 41-49.

69. Kabdaşlı, I.; Arslan-Alaton, I.; Ölmez-Hanc1, T.; Tünay, O. Electrocoagulation applications for industrial wastewaters: A critical review. Environ. Technol. Rev. 2012, 1, 2-45. [CrossRef]

(C) 2017 by the authors; licensee MDPI, Basel, Switzerland. This article is an open access article distributed under the terms and conditions of the Creative Commons Attribution (CC BY) license (http:/ / creativecommons.org/licenses/by/4.0/). 